\title{
Palladium(II) Complexes with N-Phosphine Oxide-Substituted Imidazolylidenes (PoxIms): Coordination Chemistry and Catalysis
}

Lorenzo Branzi, ${ }^{\dagger}$ Dario Franco, ${ }^{\dagger}$ Marco Baron, ${ }^{\dagger}$ Lidia Armelao, ${ }^{\dagger}{ }^{\dagger}$ Marzio Rancan, ${ }^{\dagger}$ Paolo Sgarbossa ${ }^{\S}$ and Andrea Biffis*,,

† Dipartimento di Scienze Chimiche, Università degli Studi di Padova, Via F. Marzolo 1, 35131 Padova, Italy. E-mail andrea.biffis @ unipd.it

† ICMATE-CNR, Via F. Marzolo 1, 35131 Padova, Italy.

$\S$ Dipartimento di Ingegneria Industriale, Università degli Studi di Padova, Via F. Marzolo 9, 35131

Padova, Italy.

\section{Supporting Information}

Crystal data and structure refinement of the new compounds $\quad$ S2

$\begin{array}{ll}\text { Refinement details } & \text { S4 }\end{array}$

${ }^{1} \mathrm{H},{ }^{13} \mathrm{C},{ }^{31} \mathrm{P}$ NMR spectra of the new compounds $\quad$ S8 
Table S1: Crystal data and structure refinement for compounds 7, 9 and $\mathbf{9 b .}$

\begin{tabular}{|c|c|c|c|}
\hline & 7 & 9 & $9 b$ \\
\hline Empirical Formula & $\mathrm{C}_{41} \mathrm{H}_{62} \mathrm{ClF}_{3} \mathrm{~N}_{4} \mathrm{O}_{5} \mathrm{P}_{2} \mathrm{PdS}$ & $\mathrm{C}_{42} \mathrm{H}_{62} \mathrm{~F}_{6} \mathrm{~N}_{4} \mathrm{O}_{8} \mathrm{P}_{2} \mathrm{PdS}_{2}$ & $\mathrm{C}_{43} \mathrm{H}_{65} \mathrm{~F}_{3} \mathrm{~N}_{5} \mathrm{O}_{5} \mathrm{P}_{2} \mathrm{PdS}$ \\
\hline Formula weight & 983.79 & 1097.41 & 989.40 \\
\hline Temperature/K & 297.9(4) & $298(2)$ & $296.9(8)$ \\
\hline Crystal system & Monoclinic & Triclinic & Monoclinic \\
\hline Space group & $\mathrm{P} 21 / \mathrm{n}$ & $\mathrm{P}-1$ & $\mathrm{P} 2{ }_{1} / \mathrm{c}$ \\
\hline $\mathrm{a} / \AA$ & $11.9263(7)$ & $10.2989(3)$ & $11.6478(3)$ \\
\hline $\mathrm{b} / \AA$ & $31.6908(18)$ & $10.3730(2)$ & $25.0795(5)$ \\
\hline $\mathrm{c} / \AA$ & $13.7638(10)$ & $12.2902(3)$ & $20.0051(6)$ \\
\hline$\alpha /^{\circ}$ & 90 & $90.003(2)$ & 90 \\
\hline$\beta /{ }^{\circ}$ & $102.086(6)$ & $103.366(2)$ & $101.536(2)$ \\
\hline$\gamma /{ }^{\circ}$ & 90 & $105.054(2)$ & 90 \\
\hline Volume $/ \AA^{3}$ & $5086.8(6)$ & $1231.04(5)$ & $5725.9(3)$ \\
\hline Z & 4 & 1 & 4 \\
\hline$\rho_{\text {calc }} / \mathrm{cm}^{3}$ & 1.285 & 1.480 & 1.148 \\
\hline$\mu / \mathrm{mm}^{-1}$ & 0.574 & 5.104 & 3.892 \\
\hline $\mathrm{F}(000)$ & 2048.0 & 568.0 & 2068.0 \\
\hline Crystal size $/ \mathrm{mm}^{3}$ & $0.11 \times 0.1 \times 0.05$ & $0.08 \times 0.08 \times 0.08$ & $0.15 \times 0.05 \times 0.03$ \\
\hline Radiation & $\operatorname{MoK} \alpha(\lambda=0.71073)$ & $\mathrm{CuK} \alpha(\lambda=1.54184)$ & $\mathrm{CuK} \alpha(\lambda=1.54184)$ \\
\hline $\begin{array}{l}2 \Theta \text { range for data } \\
\text { collection }^{\circ}\end{array}$ & 4.852 to 49.426 & 7.408 to 138.35 & 5.722 to 122.668 \\
\hline Index ranges & $\begin{array}{c}-14 \leq \mathrm{h} \leq 11,-37 \leq \mathrm{k} \leq 20,-16 \leq \\
1 \leq 13\end{array}$ & $\begin{array}{c}-12 \leq \mathrm{h} \leq 12,-7 \leq \mathrm{k} \leq 12,-13 \leq \\
1 \leq 14\end{array}$ & $\begin{array}{c}-12 \leq \mathrm{h} \leq 13,-28 \leq \mathrm{k} \leq 27,-21 \leq 1 \\
\leq 22\end{array}$ \\
\hline Reflections collected & 20622 & 8779 & $1 \overline{7} 872$ \\
\hline Independent reflections & $\begin{array}{c}8652 \\
{\left[R_{\text {int }}=0.0641, R_{\text {sigma }}=0.0797\right]}\end{array}$ & $\begin{array}{c}4491 \\
{\left[R_{\text {int }}=0.0406, R_{\text {sigma }}=0.0411\right]}\end{array}$ & $\begin{array}{c}8527 \\
{[\text { Rint }=0.0581, \text { Rsigma }=0.0796]}\end{array}$ \\
\hline Data/restraints/parameters & $8652 / 44 / 552$ & $4491 / 53 / 304$ & $8527 / 71 / 560$ \\
\hline Goodness-of-fit on $\mathrm{F}^{2}$ & 1.126 & 1.024 & 1.003 \\
\hline Final $R$ indexes $[\mathrm{I}>=2 \sigma(\mathrm{I})]$ & $\mathrm{R}_{1}=0.0740, \mathrm{wR}_{2}=0.1640$ & $\mathrm{R}_{1}=0.0468, \mathrm{wR}_{2}=0.1211$ & $\mathrm{R} 1=0.0567, \mathrm{wR} 2=0.1349$ \\
\hline Final R indexes [all data] & $\mathrm{R}_{1}=0.0952, \mathrm{wR}_{2}=0.1760$ & $\mathrm{R}_{1}=0.0505, \mathrm{wR}_{2}=0.1243$ & $\mathrm{R} 1=0.0713, \mathrm{wR} 2=0.1434$ \\
\hline Largest diff. peak/hole/e $\AA^{-3}$ & $1.17 /-0.44$ & $1.30 /-0.81$ & $0.63 /-0.88$ \\
\hline CCDC number & 1901291 & 1901288 & 1901290 \\
\hline
\end{tabular}

$R_{1}=\left(\Sigma\left\|F_{o}|-| F_{c}\right\| / \Sigma\left|F_{o}\right|\right) ; w R_{2}=\left\{\Sigma\left[w\left(F_{o}^{2}-F_{c}^{2}\right)^{2}\right] / \Sigma\left[\mathrm{w}\left(F_{o}^{2}\right)^{2}\right]\right\}^{1 / 2}$

$\left.\mathrm{GOF}=\Sigma\left[w\left(F_{o}^{2}-F_{c}^{2}\right)^{2}\right] /(n-p)\right\}^{1 / 2}$ where $n$ is the number of data and $p$ is the number of parameters refined. 
Table S2: Crystal data and structure refinement for compounds $\mathbf{1 0}$ and $\mathbf{1 1 .}$

\begin{tabular}{|c|c|c|}
\hline & 10 & 11 \\
\hline Empirical Formula & $\mathrm{C}_{9.5} \mathrm{H}_{19} \mathrm{CINOPPd}_{0.5}$ & $\mathrm{C}_{72} \mathrm{H}_{108} \mathrm{~F}_{9} \mathrm{~N}_{6} \mathrm{O}_{12} \mathrm{P}_{3} \mathrm{Pd}_{3} \mathrm{~S}_{3}$ \\
\hline Formula weight & 282.88 & 1928.93 \\
\hline Temperature/K & 100.01 & $302.9(8)$ \\
\hline Crystal system & Monoclinic & Monoclinic \\
\hline Space group & $\mathrm{C} 2 / \mathrm{m}$ & $\mathrm{P} 2{ }_{1}$ \\
\hline $\mathrm{a} / \AA$ & $16.0468(11)$ & $10.9394(2)$ \\
\hline $\mathrm{b} / \AA$ & $13.1295(9)$ & $16.6261(3)$ \\
\hline $\mathrm{c} / \mathrm{A}$ & $15.9006(10)$ & $25.0712(4)$ \\
\hline$\alpha /^{\circ}$ & 90 & 90 \\
\hline$\beta /{ }^{\circ}$ & $108.007(2)$ & $101.790(2)$ \\
\hline$\gamma /{ }^{\circ}$ & 90 & 90 \\
\hline Volume $/ \AA^{3}$ & $3186.0(4)$ & $4463.74(14)$ \\
\hline Z & 8 & 2 \\
\hline$\rho_{\text {calc }} / \mathrm{cm}^{3}$ & 1.179 & 1.435 \\
\hline$\mu / \mathrm{mm}^{-1}$ & 0.864 & 0.796 \\
\hline $\mathrm{F}(000)$ & 1168.0 & 1980.0 \\
\hline Crystal size $/ \mathrm{mm}^{3}$ & $0.262 \times 0.23 \times 0.179$ & $0.3 \times 0.2 \times 0.2$ \\
\hline Radiation & $\operatorname{MoK} \alpha(\lambda=0.71073)$ & $\operatorname{MoK} \alpha(\lambda=0.71073)$ \\
\hline $2 \Theta$ range for data collection $/^{\circ}$ & 4.092 to 52.026 & 4.544 to 56.564 \\
\hline Index ranges & $-19 \leq \mathrm{h} \leq 19,-16 \leq \mathrm{k} \leq 16,-19 \leq 1 \leq 19$ & $-14 \leq \mathrm{h} \leq 14,-21 \leq \mathrm{k} \leq 22,-33 \leq 1 \leq 33$ \\
\hline Reflections collected & 101615 & 57528 \\
\hline Independent reflections & $\begin{array}{c}3280 \\
{[\text { Rint }=0.0281, \text { Rsigma }=0.0100]}\end{array}$ & $\begin{array}{c}20005[ \\
\left.R_{\text {int }}=0.0173, R_{\text {sigma }}=0.0167\right]\end{array}$ \\
\hline Data/restraints/parameters & $3280 / 0 / 115$ & $20005 / 689 / 987$ \\
\hline Goodness-of-fit on $\mathrm{F}^{2}$ & 1.113 & 1.060 \\
\hline Final $\mathrm{R}$ indexes $[\mathrm{I}>=2 \sigma(\mathrm{I})]$ & $\mathrm{R} 1=0.0735, \mathrm{wR} 2=0.2241$ & $\mathrm{R}_{1}=0.0414, \mathrm{wR}_{2}=0.1114$ \\
\hline Final R indexes [all data] & $\mathrm{R} 1=0.0754, \mathrm{wR} 2=0.2259$ & $\mathrm{R}_{1}=0.0438, \mathrm{wR}_{2}=0.1137$ \\
\hline Largest diff. peak/hole/e $\AA^{-3}$ & $4.98 /-1.11$ & $0.84 /-0.52$ \\
\hline Flack parameter & --- & $-0.016(4)$ \\
\hline CCDC number & 1902487 & 1901289 \\
\hline
\end{tabular}


Table S3. Selected bond distances $(\AA)$ and angles $\left(^{\circ}\right)$ for the X-ray structure of 7, 9, 9b, 10 and 11.

\begin{tabular}{|c|c|c|c|c|c|}
\hline & 7 & 9 & $9 b$ & 10 & $11^{[\mathrm{a}]}$ \\
\hline $\mathrm{Pd}-\mathrm{Cl}$ & $2.264(2)(\mathrm{Pd} 1-\mathrm{Cl1})$ & & & $\begin{array}{l}2.294(2)_{(\mathrm{Pd} 1-\mathrm{Cl1})} \\
2.342(2)_{(\mathrm{Pd} 1-\mathrm{Cl} 2)} \\
\left.2.382(2)_{(\mathrm{Pd} 1-\mathrm{Cl} 2}{ }^{\prime}\right)\end{array}$ & \\
\hline $\mathrm{Pd}-\mathrm{O}$ & $\begin{array}{l}2.107(4)_{(\mathrm{Pd} 1-\mathrm{O} 1)} \\
\left.2.814_{(\mathrm{Pd} 1 \cdots \mathrm{O} 2}\right)^{[\mathrm{b}]}\end{array}$ & $2.032_{(\mathrm{Pd} 1-\mathrm{O} 4)}$ & $\begin{array}{c}2.065(3)_{(\mathrm{Pd} 1-\mathrm{O} 1)} \\
\left.2.697(4)_{(\mathrm{Pd} 1 \cdots \mathrm{O} 2}\right)^{[\mathrm{b}]}\end{array}$ & $2.8800(2)_{(\mathrm{Pd} 1 \cdots \mathrm{O} 2)^{[\mathrm{b}]}}$ & $2.162(4)_{(\mathrm{Pd} 1-\mathrm{O} 1)}$ \\
\hline $\mathrm{Pd}-\mathrm{C}_{\mathrm{c}}$ & $\begin{array}{l}2.034(5)_{(\mathrm{Pd} 1-\mathrm{C} 1)} \\
2.032(5)_{(\mathrm{Pd} 1-\mathrm{C} 20)}\end{array}$ & 2.026 (Pd1-C9) & $\begin{array}{l}2.027(4)_{(\mathrm{Pd} 1-\mathrm{C} 1)} \\
2.053(4)_{(\mathrm{Pd} 1-\mathrm{C} 20)}\end{array}$ & $1.952(8)_{(\mathrm{Pd} 1-\mathrm{Cl})}$ & $2.028(6)(\mathrm{P} 1-\mathrm{C} 1)$ \\
\hline $\mathrm{P}-\mathrm{O}$ & $\begin{array}{l}1.502(4)_{(\mathrm{P} 1-\mathrm{O} 1)} \\
\left.1.468(4)_{(\mathrm{P} 2-\mathrm{O} 2}\right)\end{array}$ & $1.509(4)(\mathrm{P} 2-\mathrm{O} 4)$ & $\begin{array}{l}1.504(4)_{(\mathrm{P} 1-\mathrm{O} 1)} \\
1.428(4)_{(\mathrm{P} 2-\mathrm{O} 2)}\end{array}$ & $1.508(6)_{(\mathrm{P} 1-\mathrm{O} 1)}$ & $1.488(4)_{(\mathrm{P} 1-\mathrm{O} 1)}$ \\
\hline $\mathrm{P}-\mathrm{N}$ & $1.725(5)_{(\mathrm{P} 2-\mathrm{N} 2)}$ & $1.721(3)_{(\text {(P2-N5) }}$ & $\begin{array}{l}1.720(4)_{(\mathrm{P} 1-\mathrm{N} 1)} \\
1.754(4)_{(\mathrm{P} 2-\mathrm{N} 3)}\end{array}$ & $1.731(7)_{(\mathrm{P} 1-\mathrm{N} 1)}$ & $1.729(5)_{(\mathrm{P} 1-\mathrm{N} 1)}$ \\
\hline $\mathrm{C}_{\mathrm{c}}-\mathrm{Pd}-\mathrm{C}_{\mathrm{c}}$ & $175.2(2)_{(\mathrm{C} 1-\mathrm{Pd} 1-\mathrm{C} 20)}$ & $180.00(4)_{\left(\mathrm{C} 9-\mathrm{Pd} 1-\mathrm{C} 9^{\prime}\right)}$ & $173.34(19)_{(\mathrm{C} 1-\mathrm{Pd} 1-\mathrm{C} 20)}$ & & \\
\hline $\mathrm{C}_{\mathrm{c}}-\mathrm{Pd}-\mathrm{Cl}$ & $\begin{array}{l}\text { 88.9(2)(C20-Pd1-Cl1) } \\
95.2(2)_{(\mathrm{C} 1-\mathrm{Pd} 1-\mathrm{Cl1})}\end{array}$ & & & $\begin{array}{c}88.3(3)_{(\mathrm{Cl} 1-\mathrm{Pd} 1-\mathrm{Cl1})} \\
93.2(3)_{(\mathrm{Cl} 1 \mathrm{Pd1}-\mathrm{Cl} 2)} \\
\left.179.5(2)_{(\mathrm{Cl} 1-\mathrm{Pd}-\mathrm{Cl} 2}\right)\end{array}$ & \\
\hline $\mathrm{C}_{\mathrm{c}}-\mathrm{Pd}-\mathrm{O}$ & $\begin{array}{l}83.0(2)_{(\mathrm{C} 1-\mathrm{Pd} 1-\mathrm{O} 1)} \\
93.2(2)_{(\mathrm{C} 20-\mathrm{Pd} 1-\mathrm{O} 1)}\end{array}$ & $\begin{array}{l}83.36(13)_{(\mathrm{C} 9-\mathrm{Pd} 1-O 4)} \\
\left.96.64(13)_{(\mathrm{C} 9-\mathrm{Pd} 1-04}\right)\end{array}$ & $\begin{array}{l}82.79(15)_{\left(\mathrm{C} 1-\mathrm{Pd} 1 \_O 1\right)} \\
92.67(15)_{(\mathrm{C} 20-\mathrm{Pd} 1-\mathrm{O} 1)}\end{array}$ & & $81.66(19)_{(\mathrm{C} 1-\mathrm{Pd} 1-\mathrm{O} 1)}$ \\
\hline Others & $172.7(1)$ (C11-Pd1-O1) & $180.00(3)(\mathrm{O} 4-P d 1-O 4)$ & & $\begin{array}{l}178.46(7)(\mathrm{Cl1}-\mathrm{Pd} 1-\mathrm{Cl} 2) \\
\left.91.18(7)_{(\mathrm{Cl1}-\mathrm{Pd1} 1-\mathrm{Cl} 2}\right) \\
\left.87.29(8)_{(\mathrm{Cl} 2-\mathrm{Pd} 1-\mathrm{Cl} 2}\right) \\
\left.92.72(8)_{(\mathrm{Pd} 1-\mathrm{Cl} 2-\mathrm{Pd} 1}\right)\end{array}$ & $\begin{array}{l}170.8(3)(\mathrm{C} 1-\mathrm{Pd} 1-\mathrm{C} 4) \\
171.9(3)(\mathrm{O} 1-\mathrm{Pd} 1-\mathrm{C} 2)\end{array}$ \\
\hline
\end{tabular}

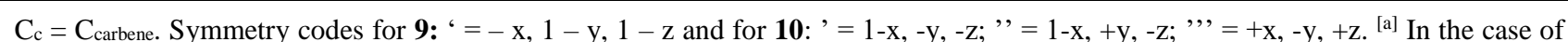
11, only the data of one of the three crystallographic independent complexes are reported, the other data are reported in Tables S1-S2. ${ }^{[b]}$ This is a non-covalent interaction.

Compound 7 refinement details. Mo $\mathrm{K} \alpha(\lambda=0.71073)$ radiation was used for data collection. Crystals were very thin plates with no appreciable diffraction lower than $0.85 \AA$. Data were collected to $0.85 \AA$ resolution, with a completeness of $100 \%$. Structural solution and refinement were carried out as described in the article experimental section. SADI, SIMU and RIGU restrains have been applied to selected bonds and atoms. The final difference Fourier map revealed a region with non-negligible residual electron density peaks that could not be effectively modelled, likely due to crystallization solvent (acetonitrile) molecules. The contribution of these peaks was removed using the mask routine of OLEX2. The program calculated a total solvent accessible volume/cell of $644.5 \AA^{3}(12.7 \%)$ and a total electron-count/cell of 74 electrons, equally divided over four main voids of $161 \AA^{3}$ bearing $19 \mathrm{ca}$. electrons per each. Such value closely fits the presence of an acetonitrile molecule in each void, hence four solvent molecules in the unit cell. 


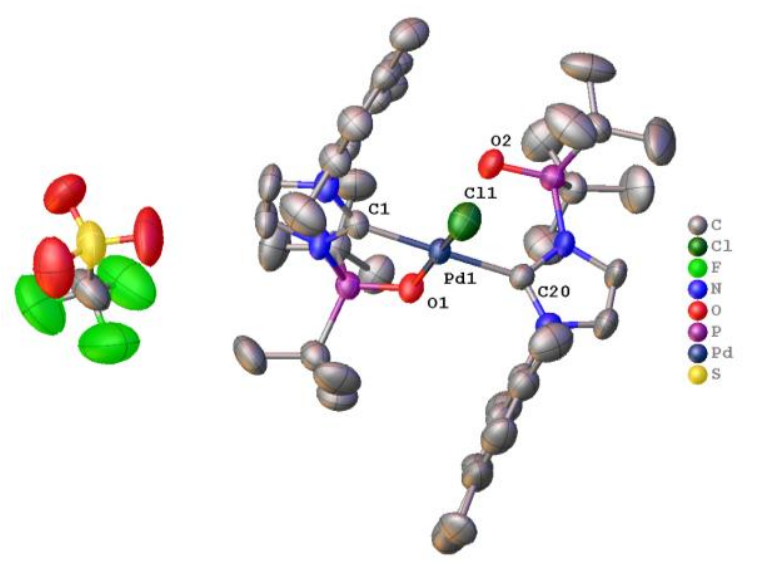

Figure S1. Asymmetric unit of 7 with thermal ellipsoids drawn at the 50\% probability level. $\mathrm{H}$ atoms omitted for clarity.

Compound 9 refinement details. $\mathrm{Cu} \mathrm{K} \alpha(\lambda=1.54184)$ radiation was used for data collection. Data were collected to $0.85 \AA$ resolution, with a completeness of $100 \%$.

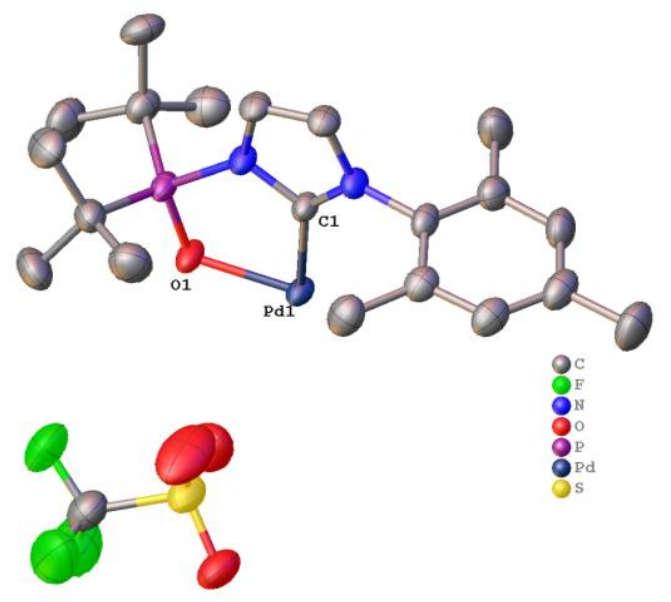

Figure S2. Asymmetric unit of 9 with thermal ellipsoids drawn at the $50 \%$ probability level. $\mathrm{H}$ atoms omitted for clarity.

Compound 9b refinement details. $\mathrm{Cu} \mathrm{K} \alpha(\lambda=1.54184)$ radiation was used for data collection. Crystals were very thin needles with no appreciable diffraction lower than $0.85 \AA$. Data were collected to $0.85 \AA$ resolution, with a completeness of $100 \%$, but during the reduction phase all the data with $a r_{i n t}>0.2$ were discarded, hence lowering the completeness to $97 \%$. The structure has a highly disordered triflate anion that could not be effectively modelled (even using several restrains and constrains) and a further region with non-negligible residual electron density peaks, likely due to crystallization solvent molecules. The mask routine of OLEX2 was applied. The program calculated a total solvent accessible volume/cell of $1300.9 \AA^{3}(22.7 \%)$ and a total electroncount/cell of 388 electrons, equally divided over two main voids of $649 \AA^{3}$ bearing 194 electrons 
per each. Such value closely fits the presence of two triflate anions and a solvent molecule (diethylether) in each void, hence a total of two solvent molecules and four anions in the unit cell, as expected for charge balancing reasons.
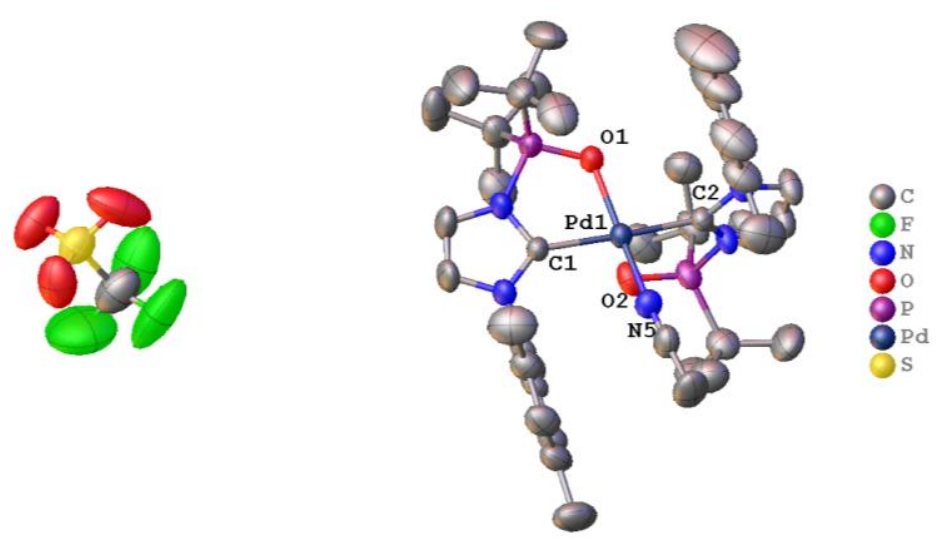

Figure S3. Asymmetric unit of $\mathbf{9 b}$ with thermal ellipsoids drawn at the $50 \%$ probability level. $\mathrm{H}$ atoms omitted for clarity.

Compound 10 refinement details. Mo $\mathrm{K} \alpha(\lambda=0.71073)$ radiation was used for data collection. Data were collected to $0.80 \AA$ resolution, with a completeness of $100 \%$. Structural solution and refinement were carried out as described in the article experimental section. The structure has a disordered $t$-butyl group, that has been treated with EADP constraint. The structure also presents a region with non-negligible residual electron density peaks, likely due to crystallization solvent molecules. The mask routine of OLEX2 was applied. The program calculated a total solvent accessible volume/cell of $979.2 \AA^{3}(30.7 \%)$ and a total electron-count/cell of 458 electrons.

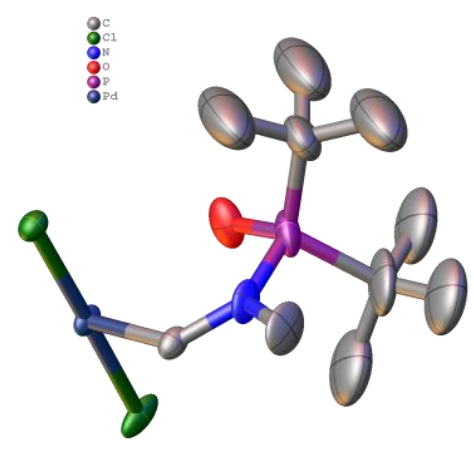

Figure S4. Asymmetric unit of $\mathbf{1 0}$ with thermal ellipsoids drawn at the $50 \%$ probability level. $\mathrm{H}$ atoms omitted for clarity.

Compound 11 refinement details. Mo $\mathrm{K} \alpha(\lambda=0.71073)$ radiation was used for data collection. Data were collected to $0.8 \AA$ resolution, with a completeness of $100 \%$. Several carbon atoms, and the oxygen and fluorine atoms of a triflate anion were disordered over two sites, the occupancies of 
which were constrained to sum to 1.0. To better model this disorder, SADI and RIGU restrains coupled to EADP constrains have been applied.

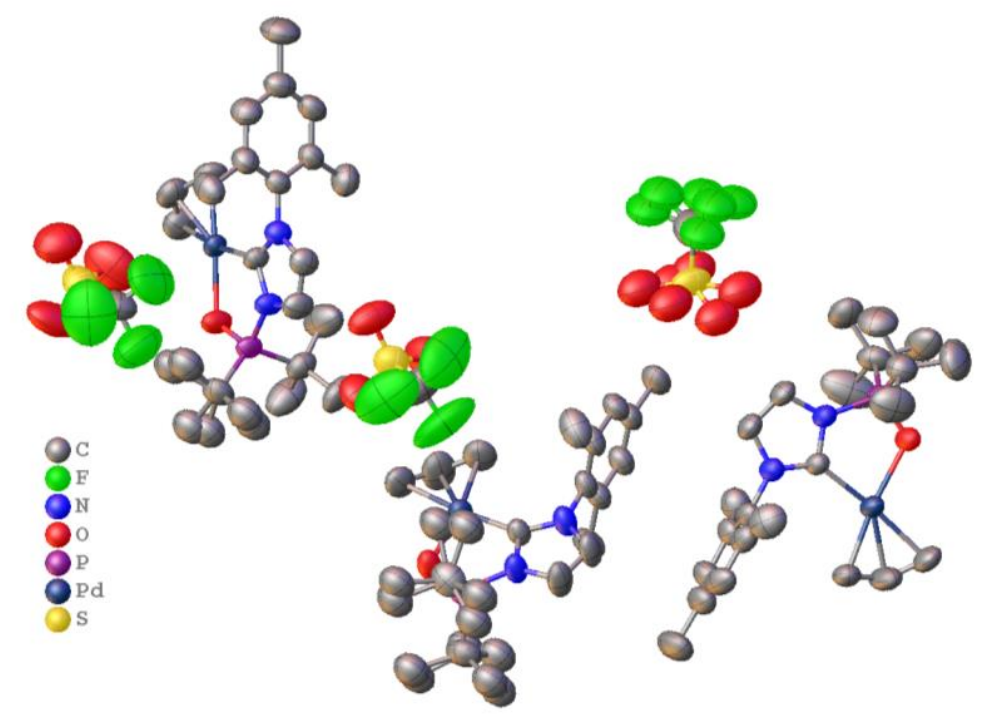

Figure S5. Asymmetric unit of $\mathbf{1 1}$ with thermal ellipsoids drawn at the 50\% probability level. $\mathrm{H}$ atoms omitted for clarity. 


\section{Compound $7{ }^{1} \mathrm{H},{ }^{13} \mathrm{C},{ }^{31} \mathrm{P}$ NMR characterization}

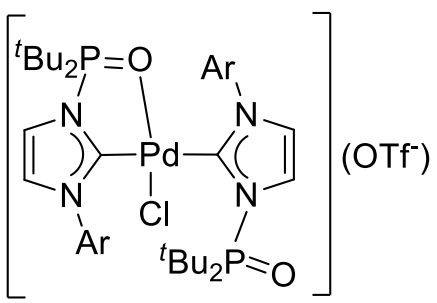

$7 \mathrm{Ar}=$ mesityl

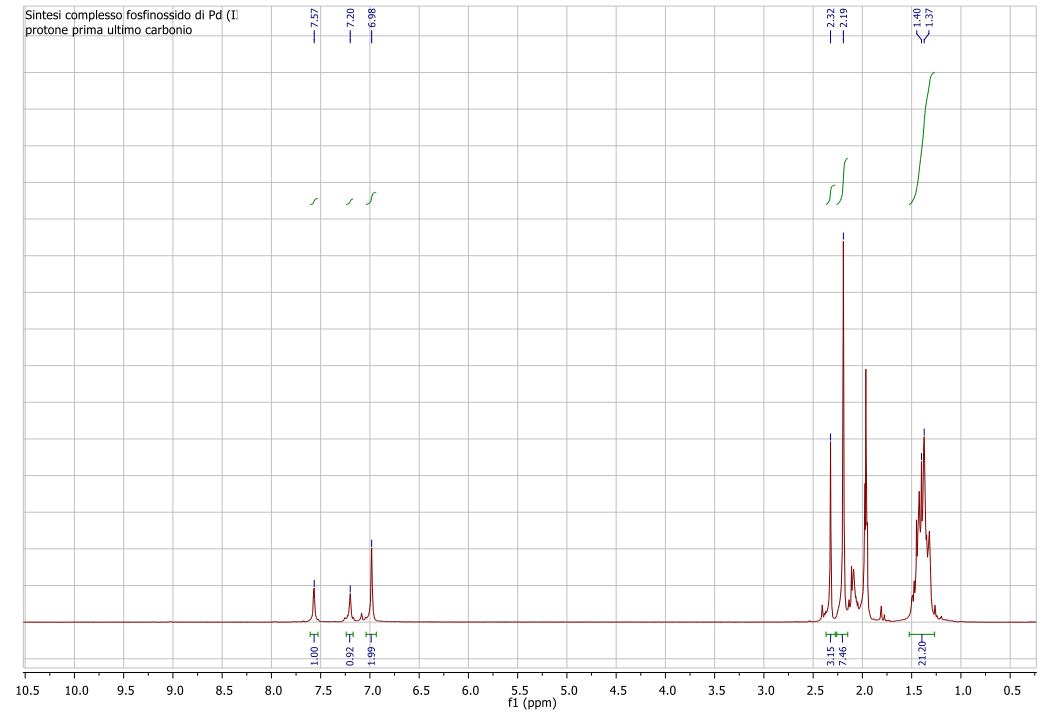

Figure S6. ${ }^{1} \mathrm{H}$ NMR spectrum of compound 7 in $\mathrm{CD}_{3} \mathrm{CN}$

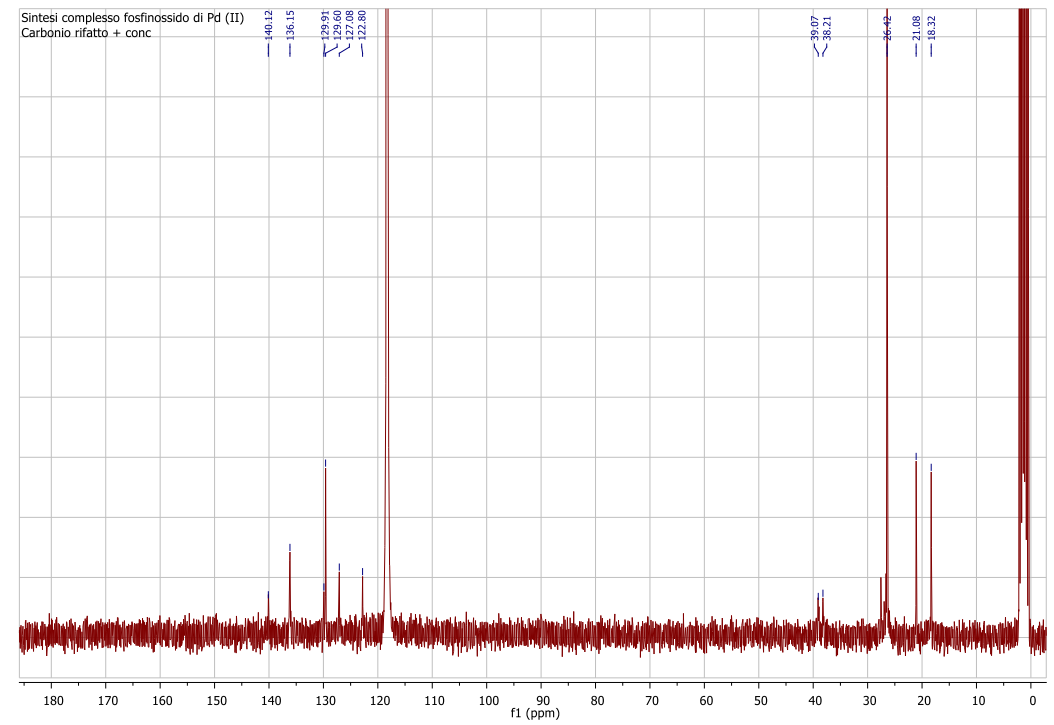

Figure S7. ${ }^{13} \mathrm{C}$ NMR spectrum of compound 7 in $\mathrm{CD}_{3} \mathrm{CN}$ 


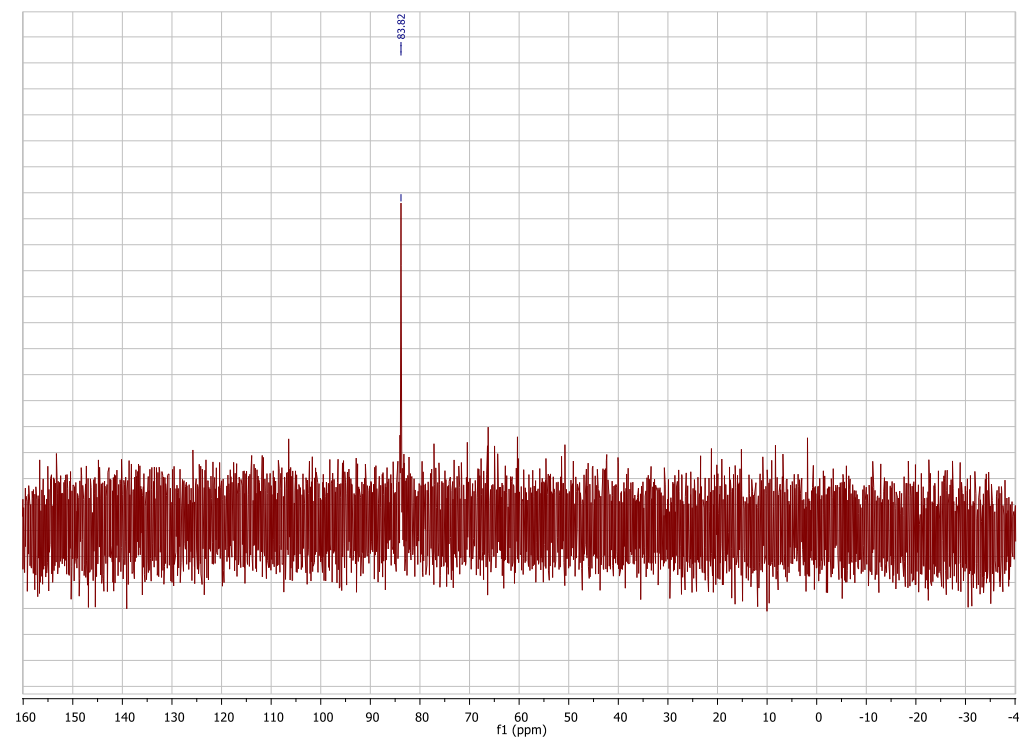

Figure S8. ${ }^{31} \mathrm{P}$ NMR spectrum of compound 7 in $\mathrm{CD}_{3} \mathrm{CN}$ 


\section{Compound $8{ }^{1} \mathrm{H},{ }^{13} \mathrm{C},{ }^{31} \mathrm{P}$ NMR characterization}

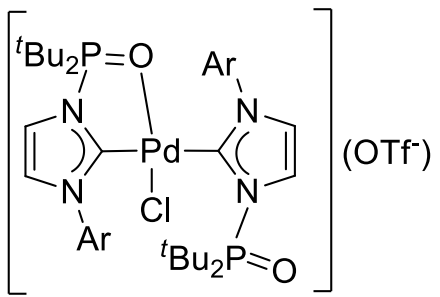

$8 \mathrm{Ar}=2,6$-di'PrPh

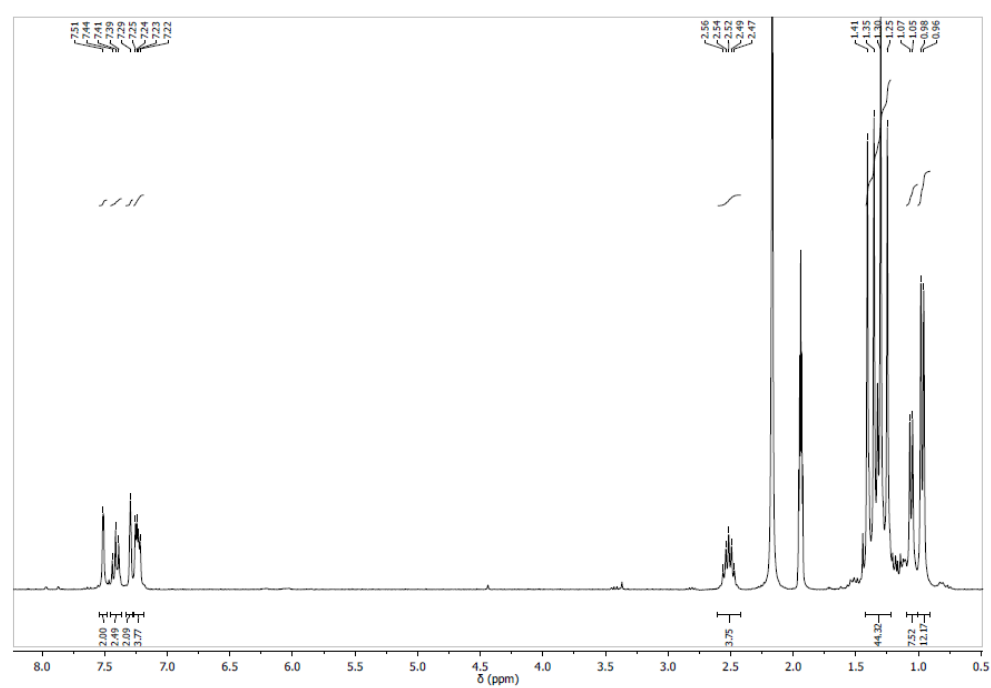

Figure S9. ${ }^{1} \mathrm{H}$ NMR spectrum of compound 8 in $\mathrm{CD}_{3} \mathrm{CN}$

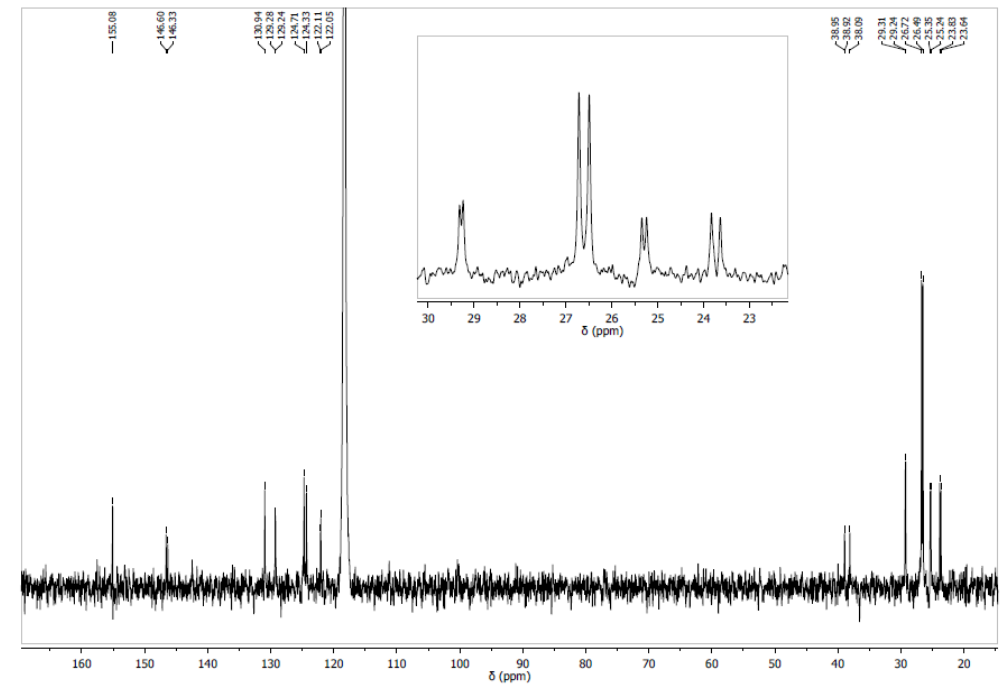

Figure S10. ${ }^{13} \mathrm{C}$ NMR spectrum of compound 8 in $\mathrm{CD}_{3} \mathrm{CN}$ 


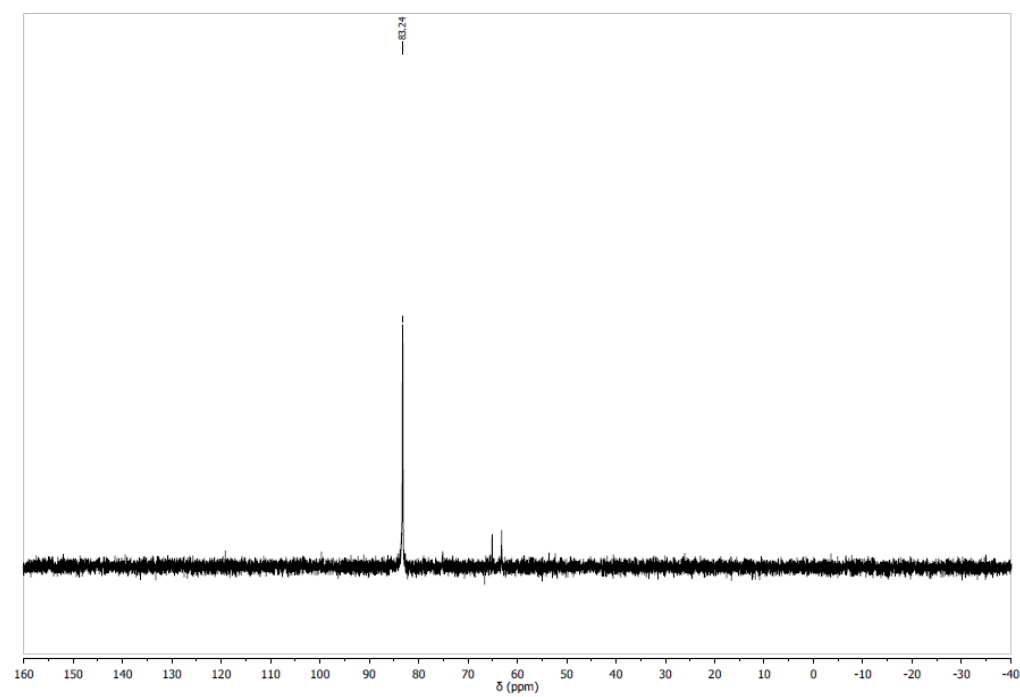

Figure S11. ${ }^{31} \mathrm{P}$ NMR spectrum of compound 8 in $\mathrm{CD}_{3} \mathrm{CN}$ 


\section{Compound $9{ }^{1} \mathrm{H},{ }^{13} \mathrm{C},{ }^{31} \mathrm{P}$ NMR characterization}

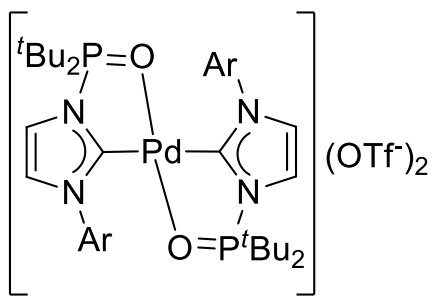

$9 \mathrm{Ar}=$ mesityl

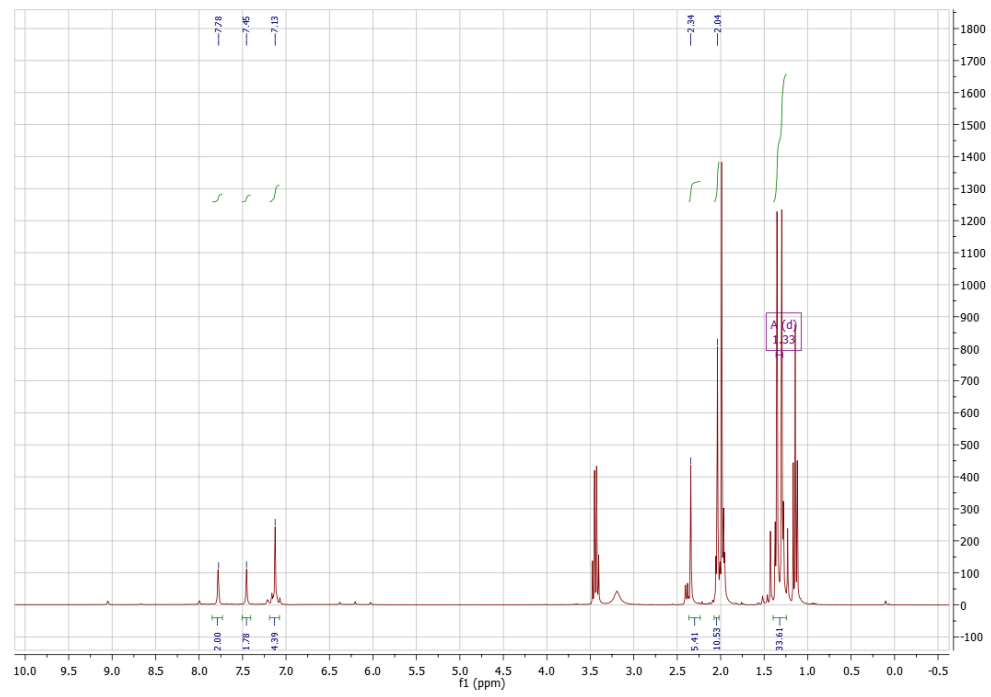

Figure S12. ${ }^{1} \mathrm{H}$ NMR spectrum of compound 9 in $\mathrm{CD}_{3} \mathrm{CN}$

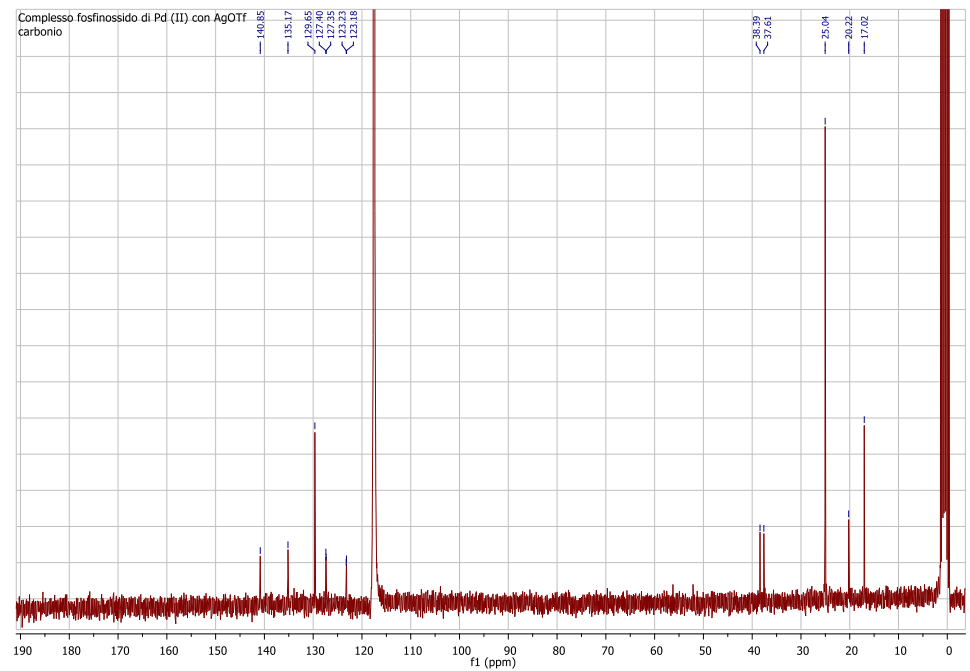

Figure S13. ${ }^{13} \mathrm{C}$ NMR spectrum of compound 9 in $\mathrm{CD}_{3} \mathrm{CN}$ 


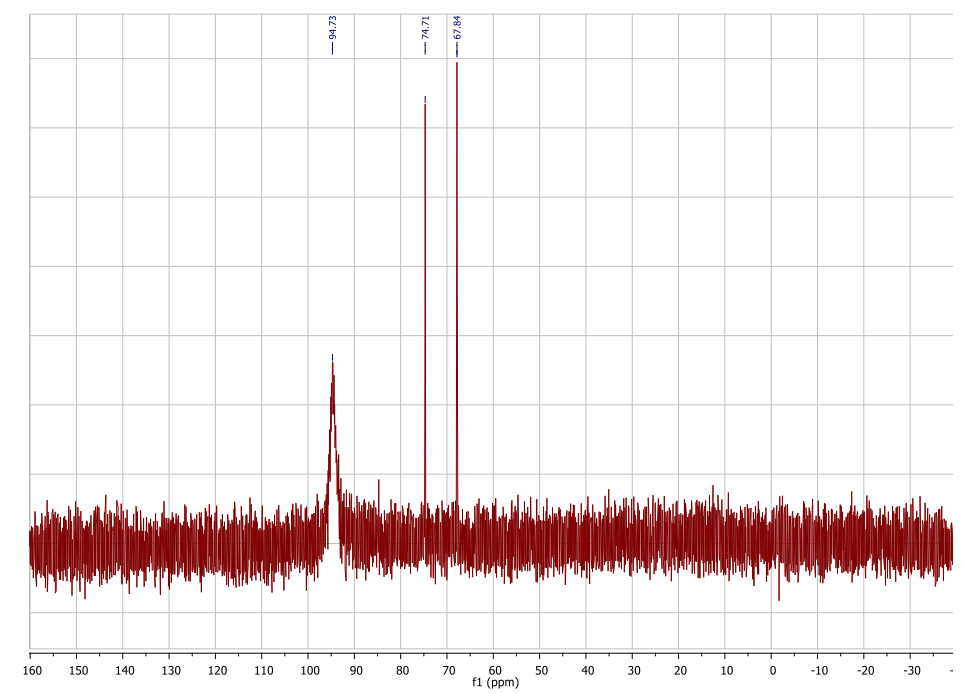

Figure S14. ${ }^{31} \mathrm{P}$ NMR spectrum of compound 9 in $\mathrm{CD}_{3} \mathrm{CN}$ 
Compound $10{ }^{1} \mathrm{H},{ }^{13} \mathrm{C},{ }^{31} \mathrm{P}$ NMR characterization

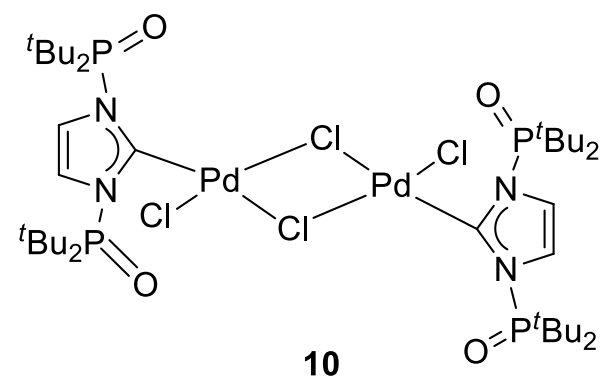

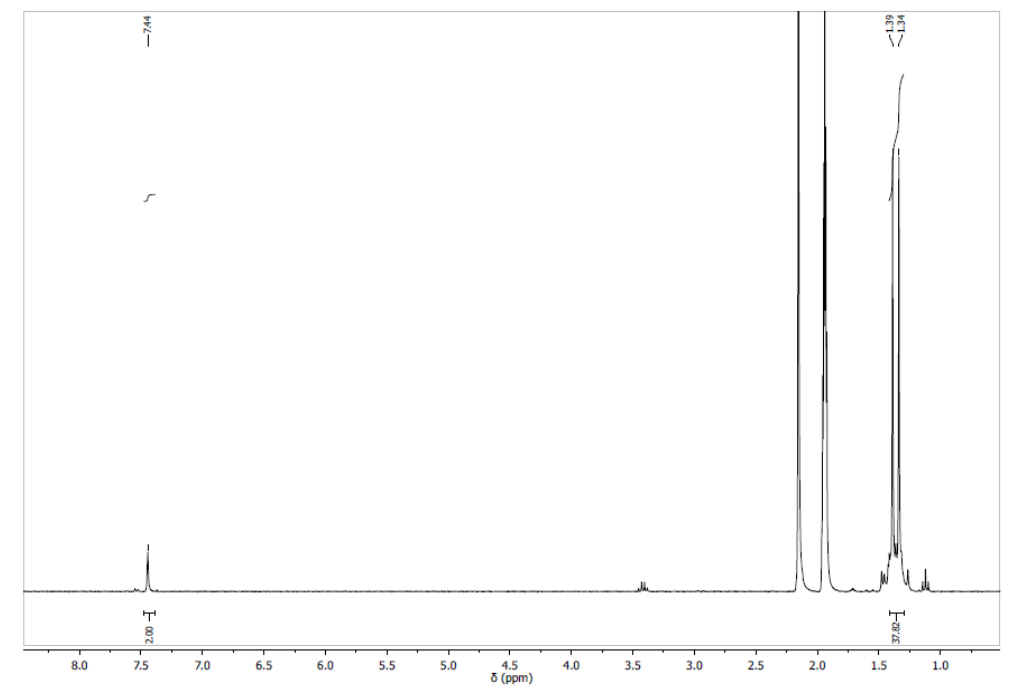

Figure S15. ${ }^{1} \mathrm{H}$ NMR spectrum of compound $\mathbf{1 0}$ in $\mathrm{CD}_{3} \mathrm{CN}$

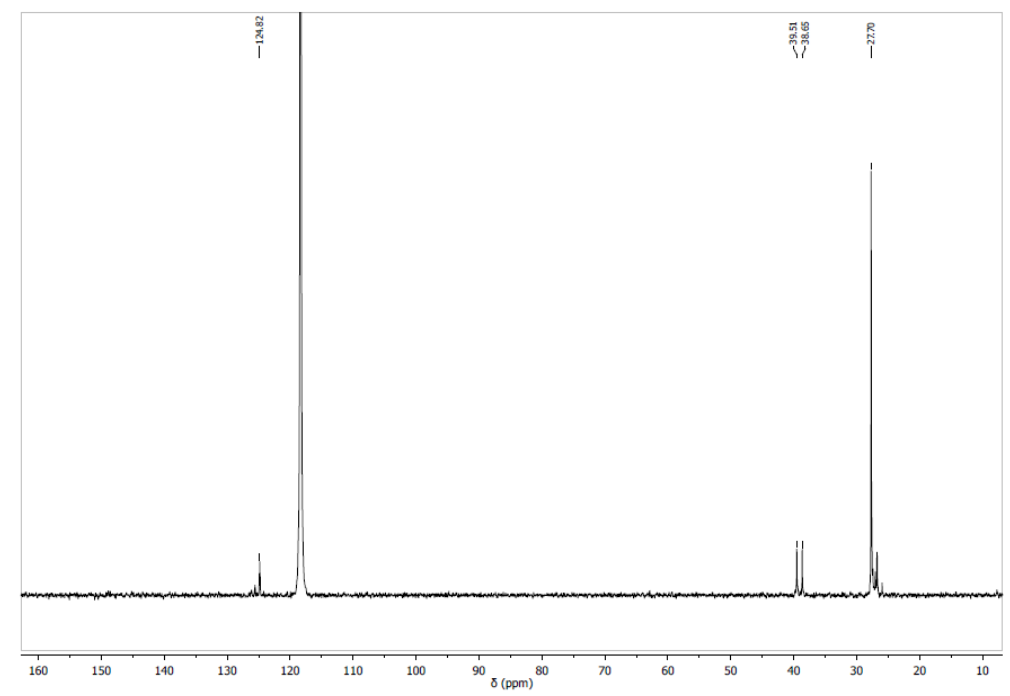

Figure S16. ${ }^{13} \mathrm{C}$ NMR spectrum of compound 10 in $\mathrm{CD}_{3} \mathrm{CN}$ 

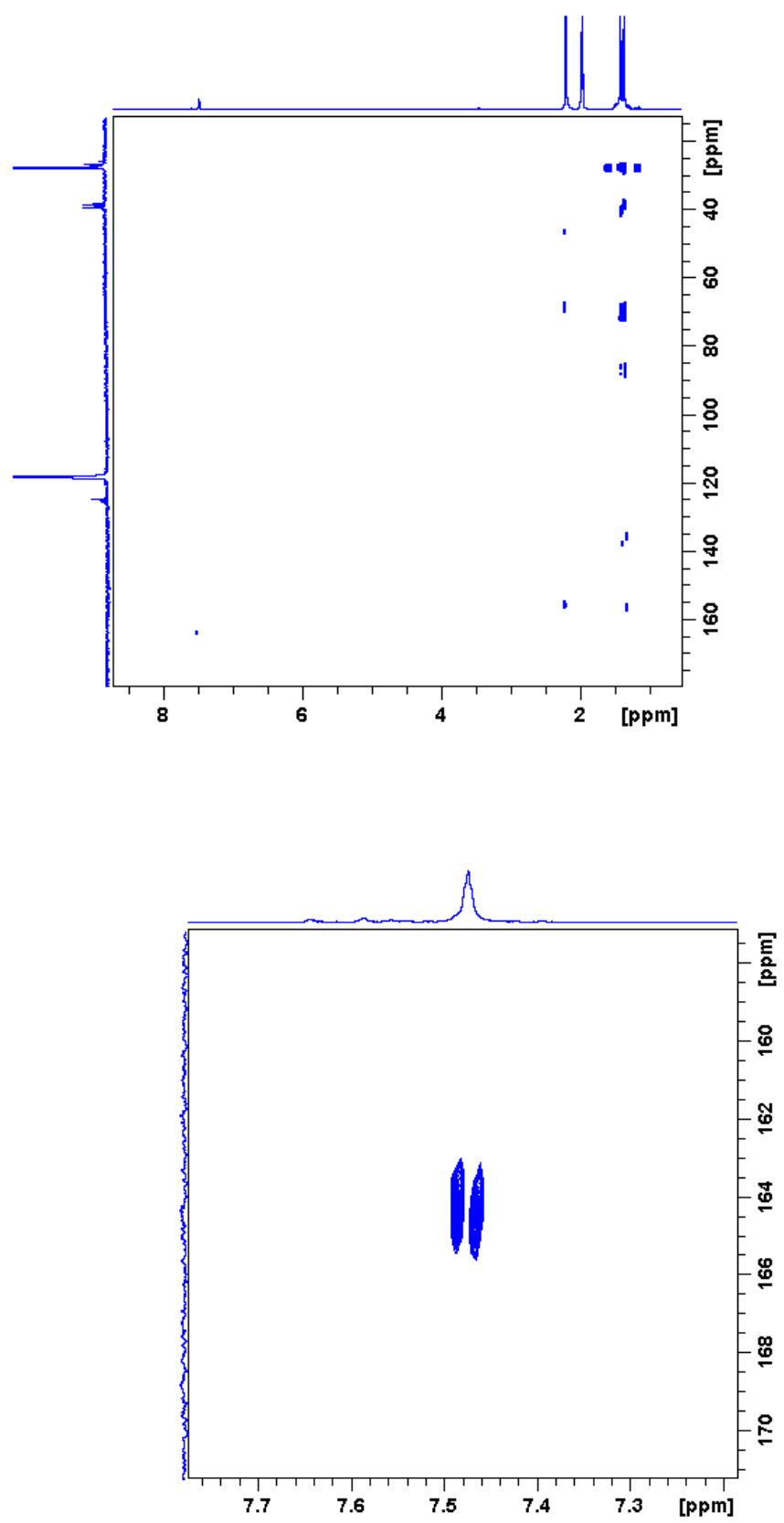

Figure S17. Long-range C-H correlation experiment (HMBC) with compound $\mathbf{1 0}$ showing the signal of the carbene carbon. Above: complete correlation map; below, magnification of the carbene region. 


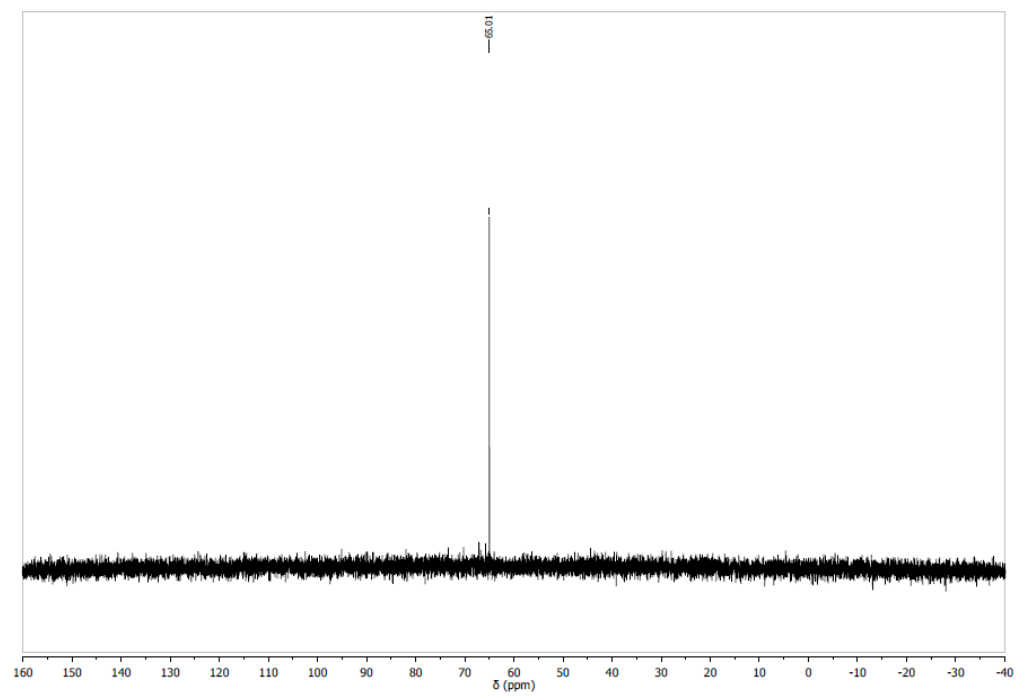

Figure S18. ${ }^{31} \mathrm{P}$ NMR spectrum of compound 10 in $\mathrm{CD}_{3} \mathrm{CN}$ 


\section{Compound $11{ }^{1} \mathrm{H},{ }^{13} \mathrm{C},{ }^{31} \mathrm{P}$ NMR characterization}

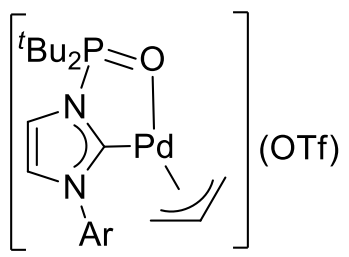

$11 \mathrm{Ar}=$ mesityl

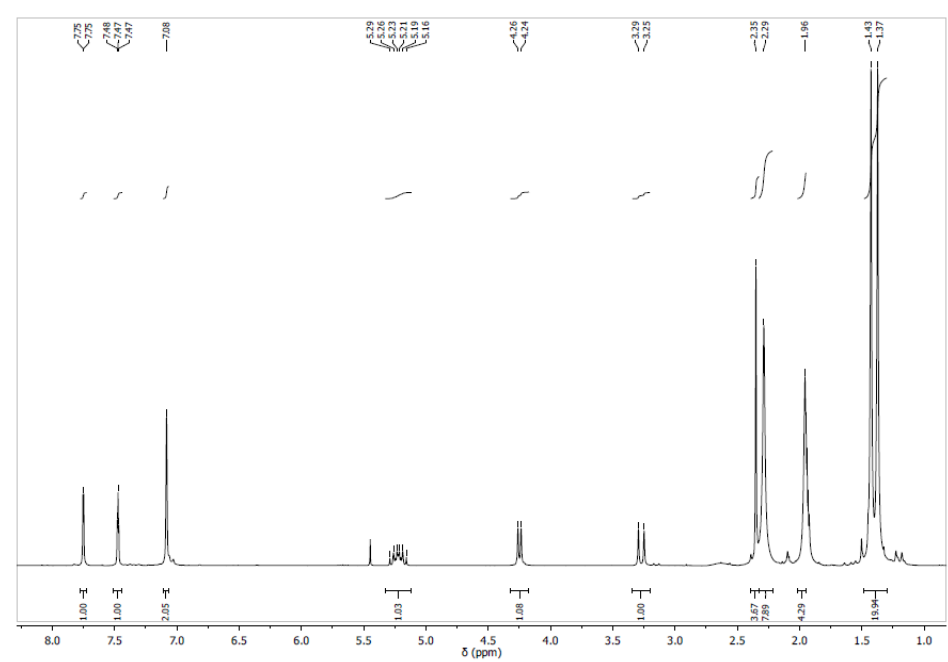

Figure S19. ${ }^{1} \mathrm{H}$ NMR spectrum of compound 11 in $\mathrm{CD}_{3} \mathrm{CN}$

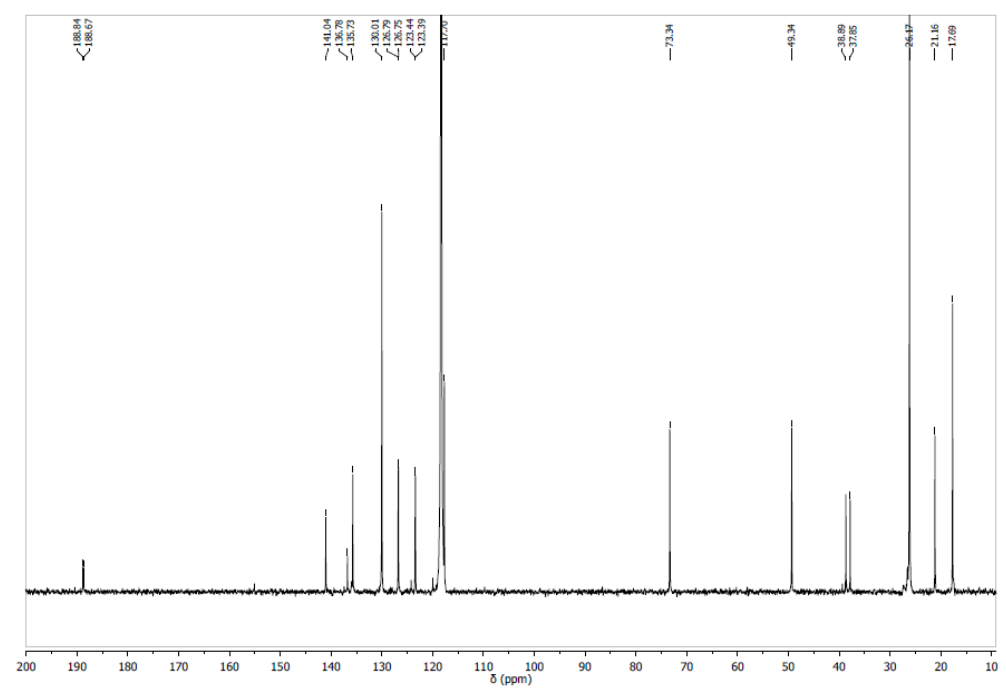

Figure S20. ${ }^{13} \mathrm{C}$ NMR spectrum of compound 11 in $\mathrm{CD}_{3} \mathrm{CN}$ 


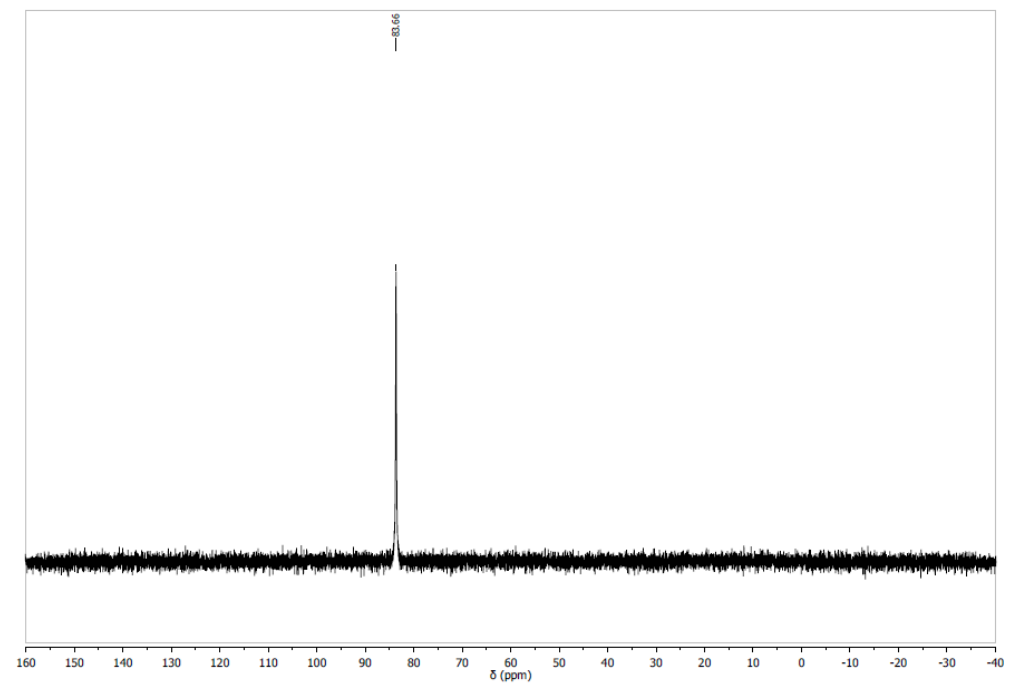

Figure S21. ${ }^{31} \mathrm{P}$ NMR spectrum of compound 11 in $\mathrm{CD}_{3} \mathrm{CN}$ 
Compound $12{ }^{1} \mathrm{H},{ }^{13} \mathrm{C},{ }^{31} \mathrm{P}$ NMR characterization $\left[\begin{array}{c}{ }^{t} \mathrm{Bu}_{2} P=0 \\ {\left[{ }_{\mathrm{Ar}}^{\mathrm{N}}>-\mathrm{Pd}\right.}\end{array}\right]($ OTf)

$12 \mathrm{Ar}=2,6-d i \mathrm{PrPh}$

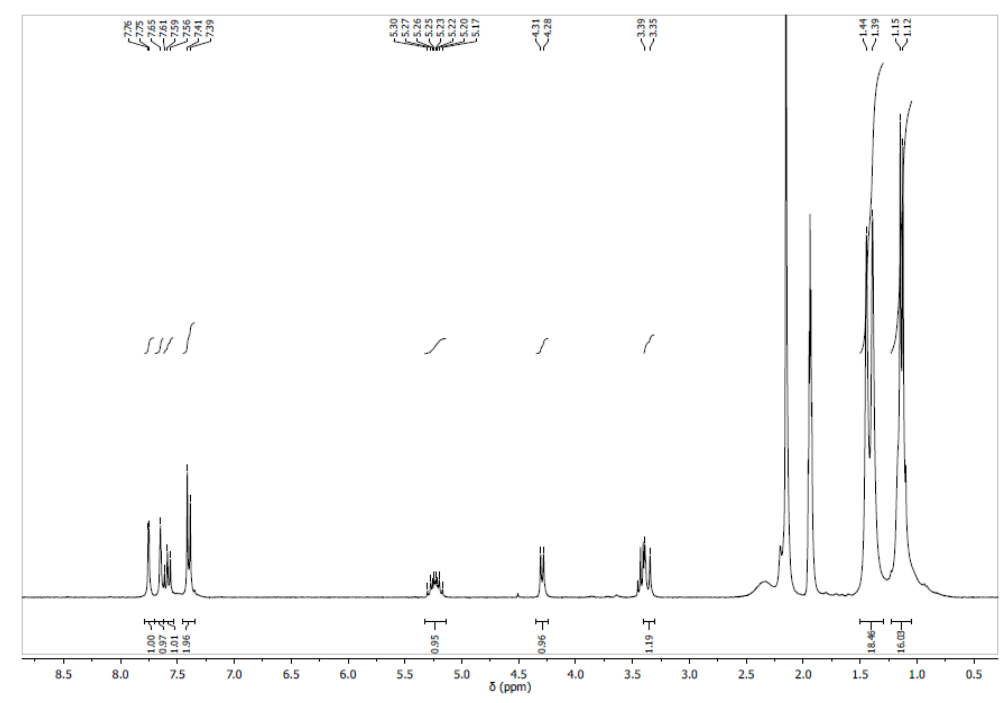

Figure S22. ${ }^{1} \mathrm{H}$ NMR spectrum of compound 12 in $\mathrm{CD}_{3} \mathrm{CN}$

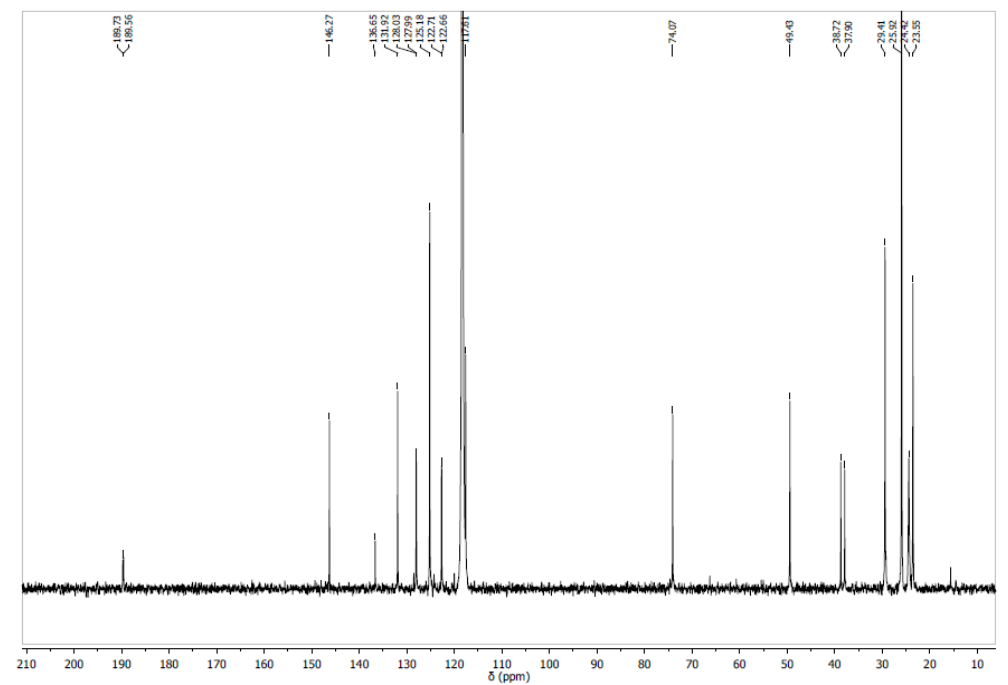

Figure S23. ${ }^{12} \mathrm{C}$ NMR spectrum of compound 12 in $\mathrm{CD}_{3} \mathrm{CN}$ 


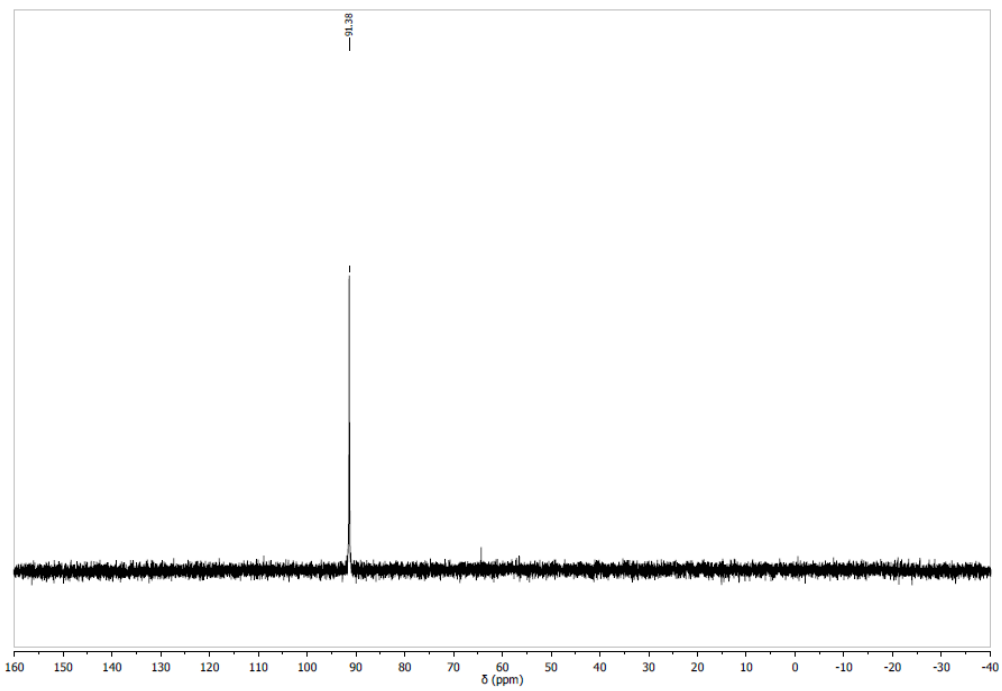

Figure S24. ${ }^{31} \mathrm{P}$ NMR spectrum of compound 12 in $\mathrm{CD}_{3} \mathrm{CN}$ 